\title{
Activity of Cathelicidin Peptides against Simkania negevensis
}

\author{
Manuela Donati, ${ }^{1}$ Antonietta Di Francesco, ${ }^{2}$ Maria Di Paolo, ${ }^{1}$ \\ Natascia Fiani, ${ }^{1}$ Monica Benincasa, ${ }^{3}$ Renato Gennaro, ${ }^{3}$ Paola Nardini, ${ }^{1}$ \\ Claudio Foschi, ${ }^{1}$ and Roberto Cevenini ${ }^{1}$ \\ ${ }^{1}$ Section of Microbiology DESOS, Policlinico S. Orsola, University of Bologna, 40138 Bologna, Italy \\ ${ }^{2}$ Department of Veterinary Medical Sciences, University of Bologna, 40064 Ozzano dell'Emilia, Italy \\ ${ }^{3}$ Department of Life Sciences, University of Trieste, 34127, Trieste, Italy
}

Correspondence should be addressed to Antonietta Di Francesco, antoniet.difrancesco@unibo.it

Received 10 December 2010; Accepted 30 January 2011

Academic Editor: Peter Bergman

Copyright (C) 2011 Manuela Donati et al. This is an open access article distributed under the Creative Commons Attribution License, which permits unrestricted use, distribution, and reproduction in any medium, provided the original work is properly cited.

The in vitro activity of six cathelicidin peptides against the reference strain $\mathrm{Z}$ of Simkania negevensis was investigated. Five peptides-PG-1, Bac7, SMAP-29, BMAP-27, and BMAP-28 - proved to be active at very low concentrations $(1$ to $0.1 \mu \mathrm{g} / \mathrm{mL})$, while LL-37 cathelicidin was ineffective even at a concentration of $100 \mu \mathrm{g} / \mathrm{mL}$. In comparison to chlamydiae, S. negevensis proved to be more susceptible to the antimicrobial peptides tested.

\section{Introduction}

Simkania negevensis is an obligate intracellular Gram-negative bacterium belonging to the family of Simkaniaceae in the order Chlamydiales [1], discovered as a contaminant in a variety of cell cultures [2], and is able to grow also in various environmental free-living amoebae such as Acanthamoeba poliphaga [3].

Epidemiologic studies have reported a human widespread exposure to this bacterium $[4,5]$, both in healthy subjects and in association with respiratory diseases in infants and adults [6-10]. Coinfections with other pathogens have been described, such as respiratory syncytial virus in children and influenza virus and other bacterial species in adults $[7,8$, 11]. A possible association between $S$. negevensis and acute rejection in lung transplant recipients has been suggested [12]. S. negevensis DNA has also been amplified from an aortic aneurysm $[13,14]$.

Previous investigations reported S. negevensis in vitro susceptibility to azithromycin, minocycline, erithromycin, doxycycline, and ofloxacin like chlamydiae [15] and the lack of susceptibility to ampicillin, penicillin G, bacitracin, cyclosporine, and fluoroquinolones $[2,15,16]$.

Several studies [17-20] demonstrated the in vitro antichlamydial activity of peptides, such as cathelicidins, stored by mammalian leucocytes and show an antimicrobial activity against bacteria, fungi, protozoa, and enveloped viruses. With regard to the mode of action of these peptides against chlamydiae, previous investigations on the activity of protegrins [21] suggested an initial binding to lipopolysaccharide followed by insertion into the membrane that results in permeabilization. Yasin et al. [22] demonstrated that the antichlamydial activity of protegrins resided especially in residues 5 to 15 of native protegrin-1 and required both intramolecular disulfide bonds.

In the present study, we investigate the in vitro activity of six antimicrobial peptides against the reference strain $\mathrm{Z}$ of $S$. negevensis.

\section{Materials and Methods}

The cathelicidin peptides-PG-1 from pig, Bac7 (1-35) from cattle, SMAP-29 from sheep, LL-37 from human, BMAP27, and BMAP-28 from cattle-were chemically synthesized, purified, characterized, and provided as lyophilized peptide, as previously reported [19]. The reference strain $Z$ of $S$. negevensis (American Type Culture Collection VR-1471) was grown in LLC-MK2 cells [23] in 6-large well plates and elementary bodies (EBs) were purified by use of sucrose gradients [24], resuspended in sucrose-phosphate-glutamic 


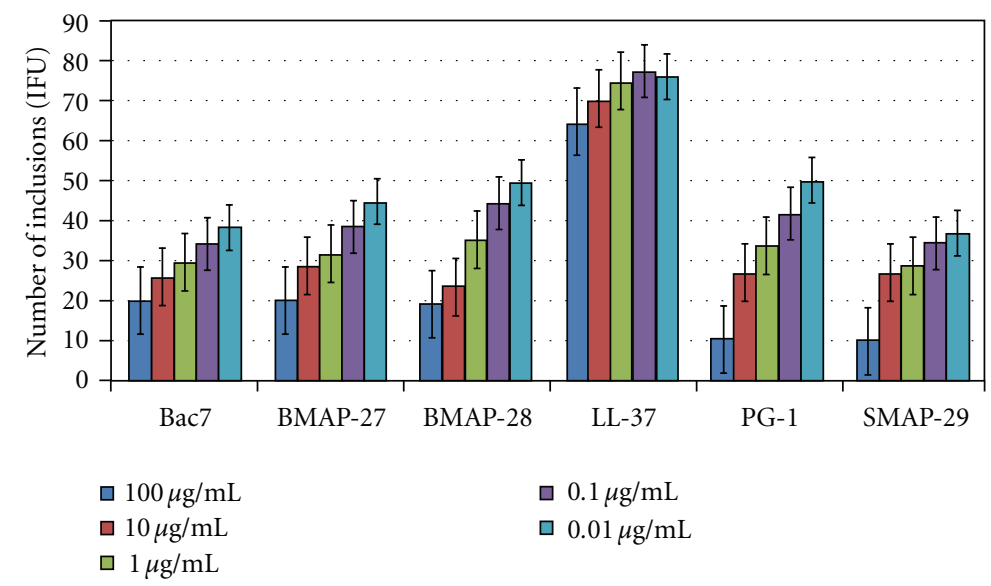

FIGURE 1: Activity of cathelicidin peptides at different concentrations on the infectivity of Simkania negevensis.

acid buffer (SPG) pH $7.4 \quad(75 \mathrm{~g}$ sucrose, $87 \mathrm{~mL} \quad 0.2 \mathrm{M}$ $\mathrm{Na}_{2} \mathrm{HPO}_{4}, 13 \mathrm{~mL} 0.2 \mathrm{M} \mathrm{NaH}_{2} \mathrm{PO}_{4}, 0.72 \mathrm{~g}$ L-glutamic acid), and frozen in aliquots at $-80^{\circ} \mathrm{C}$.

Stock solutions of each peptide at $1 \mathrm{~g} /$ liter were prepared in phosphate-buffered saline (PBS), $\mathrm{pH}$ 7.4, and stored frozen in $20-\mu \mathrm{L}$ aliquots at $-80^{\circ} \mathrm{C}$ until used. To determine the lowest peptide concentration required to achieve $\geq 50 \%$ reduction of inclusions with respect to untreated control, the various peptides were diluted tenfold from 200 to $0.02 \mu \mathrm{g} / \mathrm{mL}$, in a volume of $100 \mu \mathrm{L}$ with PBS in polypropylene tubes. An equal volume of $5 \times 10^{5}$ inclusion-forming units (IFU)/mL of purified S. negevensis EBs in SPG medium was then added, so obtaining a final cathelicidin concentration ranging from 100 to $0.01 \mu \mathrm{g} / \mathrm{mL}$ in a mixture of PBS and SPG at a final pH 7.4. EBs untreated with cathelicidins were used as a control. After incubation at room temperature for $2 \mathrm{~h}$, a $200 \mu \mathrm{L}$ aliquot was added to $800 \mu \mathrm{L}$ chlamydial growth medium and inoculated onto LLC-MK2 cells grown in 24well plates in a $5 \% \mathrm{CO}_{2}$ atmosphere. After centrifugation at $800 \times \mathrm{g}$ for $1 \mathrm{~h}$ at $33^{\circ} \mathrm{C}$ and incubation at $35^{\circ} \mathrm{C}$ for $72 \mathrm{~h}$, the cultures were fixed and stained for the presence of inclusions by immunofluorescence using an in-house rabbit polyclonal hyperimmune serum raised against $S$. negevensis. The number of IFU per coverslip was counted in 40 microscopic fields using a ZEISS UV microscope at a magnification of $\times 200$.

All tests were performed in triplicate and in three independent experiments.

\section{Results and Discussion}

The activities of the six cathelicidin peptides against $S$. negevensis are reported in Figure 1 and are the means of results from the three experiments. In comparison with the infectivity of the untreated control (mean value $74 \mathrm{IFU} / \mathrm{mL}$ ), Bac7 and SMAP-29 reduced by $>50 \%(<37 \mathrm{IFU} / \mathrm{mL})$ the inclusion numbers of $S$. negevensis at a concentration of $0.1 \mu \mathrm{g} / \mathrm{mL}$, whereas PG-1, BMAP-27 and BMAP-28 showed the same activity at a concentration of $1 \mu \mathrm{g} / \mathrm{mL}$. All these five cathelicidins demonstrated a very slow decrease in their inhibitory effect while their concentration has been reducing from 100 to 1 or $0.1 \mu \mathrm{g} / \mathrm{mL}$. LL-37 peptide did not exert any inhibitory effect, even at a concentration of $100 \mu \mathrm{g} / \mathrm{mL}$.

In our previous study [19], the activity of six cathelicidins-PG-1, Bac7, SMAP-29, BMAP-27, LL-37 and BMAP28-tested on chlamydiae of human and animal origin showed that five of them had inhibitory effect on Chlamydia trachomatis strains, SMAP-29 being the most active peptide at a concentration of $10 \mu \mathrm{g} / \mathrm{mL}$; on the contrary, LL-37 peptide was ineffective even at a concentration of $80 \mu \mathrm{g} / \mathrm{mL}$. With regard to the other chlamydial species tested, only Chlamydophila pneumoniae and Chlamydophila felis were sensitive to $10 \mu \mathrm{g} / \mathrm{mL}$ of SMAP-29 and $80 \mu \mathrm{g} / \mathrm{mL}$ of SMAP29/Bac7, respectively.

In the present investigation, the same six cathelicidins were tested against the reference strain $\mathrm{Z}$ of $\mathrm{S}$. negevensis. In comparison with chlamydiae, $S$. negevensis was not sensitive to LL-37 even at the concentration of $80 \mu \mathrm{g} / \mathrm{mL}$, but very sensitive to all the other five cathelicidins that showed an inhibitory effect at very low concentrations from 1 to $0.1 \mu \mathrm{g} / \mathrm{mL}$. To our knowledge no study on $S$. negevensis susceptibility to cathelicidins has been performed, until now. These preliminary results suggest a higher sensitivity of $S$. negevensis to cathelicidins respect to chlamydiae. A previous study showed differences in the susceptibility of different $C$. trachomatis serovars to antimicrobial peptides, suggesting that limited variations in the disulfide bonding in the membrane structure of these organisms may influence their susceptibility to peptides [18]. The membrane structure of $S$. negevensis probably differs significantly from that of other members of Chlamydiales, as monoclonal antibodies recognizing family-specific epitopes of chlamydial OMP-2, MOMP, and LPS did not bind S. negevensis antigens [2, 25]; in addition, only a relatively small number of common epitopes were shown to be shared when $S$. negevensis and other Chlamydiales members were tested for cross-reactivity by Western blot using polyclonal antisera [26]. The higher 
susceptibility of $S$. negevensis to cathelicidins in comparison to chlamydiae could be referred, to a great extent, to its different polypeptides pattern.

\section{References}

[1] K. D. E. Everett, R. M. Bush, and A. A. Andersen, "Emended description of the order Chlamydiales, proposal of Parachlamydiaceae fam. nov. and Simkaniaceae fam. nov., each containing one monotypic genus, revised taxonomy of the family Chlamydiaceae, including a new genus and five new species, and standards for the identification of organisms," International Journal of Systematic Bacteriology, vol. 49, no. 2, pp. 415-440, 1999.

[2] S. Kahane, R. Gonen, C. Sayada, J. Elion, and M. G. Friedman, "Description and partial characterization of a new chlamydialike microorganism," FEMS Microbiology Letters, vol. 109, no. 2-3, pp. 329-334, 1993.

[3] S. Kahane, B. Dvosktn, M. Mathias, and M. G. Friedman, "Infection of Acanthamoeba polyphaga with Simkania negevensis and S. negevensis survival within amoebal cysts," Applied and Environmental Microbiology, vol. 67, no. 10, pp. 4789-4795, 2001.

[4] S. Kahane, D. Greenberg, D. Lieberman et al., "The novel microorganism " $Z$ " is capable of infecting humans," in Proceedings of the 3rd Meeting of the European Society for Chlamydial Research, A. Stary, Ed., p. 18, Vienna, Austria, 1996.

[5] M. G. Friedman, A. Galil, S. Greenberg, and S. Kahane, "Seroprevalence of IgG antibodies to the chlamydia-like microorganism 'Simkania $Z$ ' by ELISA," Epidemiology and Infection, vol. 122, no. 1, pp. 117-123, 1999.

[6] D. Lieberman, S. Kahane, D. Lieberman, and M. G. Friedman, "Pneumonia with serological evidence of acute infection with the chlamydia-like microorganism ' $Z$ ', American Journal of Respiratory and Critical Care Medicine, vol. 156, no. 2, pp. 578582, 1997.

[7] S. Kahane, D. Greenberg, M. G. Friedman, H. Haikin, and R. Dagan, "High prevalence of 'Simkania $Z$ ' a novel chlamydialike bacterium, in infants with acute bronchiolitis," Journal of Infectious Diseases, vol. 177, no. 5, pp. 1425-1429, 1998.

[8] D. Lieberman, B. Dvoskin, D. V. Lieberman, S. Kahane, and M. G. Friedman, "Serological evidence of acute infection with the chlamydia-like microorganism Simkania negevensis $(\mathrm{Z})$ in acute exacerbation of chronic obstructive pulmonary disease," European Journal of Clinical Microbiology and Infectious Diseases, vol. 21, no. 4, pp. 307-309, 2002.

[9] L. Fasoli, M. Paldanius, M. Don et al., "Simkania negevensis in community-acquired pneumonia in Italian children," Scandinavian Journal of Infectious Diseases, vol. 40, no. 3, pp. 269 272, 2008.

[10] T. Heiskanen-Kosma, M. Paldanius, and M. Korppi, "Simkania negevensis may be a true cause of community acquired pneumonia in children," Scandinavian Journal of Infectious Diseases, vol. 40, no. 2, pp. 127-130, 2008.

[11] D. Greenberg, A. Banerji, M. G. Friedman, C. H. Chiu, and S. Kahane, "High rate of Simkania negevensis among Canadian inuit infants hospitalized with lower respiratory tract infections," Scandinavian Journal of Infectious Diseases, vol. 35, no. 8, pp. 506-508, 2003.

[12] S. Husain, S. Kahane, M. G. Friedman et al., "Simkania negevensis in bronchoalveolar lavage of lung transplant recipients: a possible association with acute rejection," Transplantation, vol. 83, no. 2, pp. 138-143, 2007.
[13] J. M. Ossewaarde and A. Meijer, "Molecular evidence for the existence of additional members of the order Chlamydiales," Microbiology, vol. 145, no. 2, pp. 411-417, 1999.

[14] M. G. Friedman, B. Dvoskin, and S. Kahane, "Infections with the chlamydia-like microorganism Simkania negevensis, a possible emerging pathogen," Microbes and Infection, vol. 5, no. 11, pp. 1013-1021, 2003.

[15] S. Kahane and M. G. Friedman, "Antibiotic sensitivities in vitro of Simkania negevensis," in Proceedings of the 4th Meeting of the European Society for Chlamydial Research, P. Saikku, Ed., p. 397, Bologna, Italy, 2000.

[16] N. Casson and G. Greub, "Resistance of different Chlamydialike organisms to quinolones and mutations in the quinoline resistance-determining region of the DNA gyrase Aand topoisomerase-encoding genes," International Journal of Antimicrobial Agents, vol. 27, no. 6, pp. 541-544, 2006.

[17] B. Yasin, S. S. L. Harwig, R. I. Lehrer, and E. A. Wagar, "Susceptibility of Chlamydia trachomatis to protegrins and defensins," Infection and Immunity, vol. 64, no. 3, pp. 709-713, 1996.

[18] C. Chong-Cerrillo, M. E. Selsted, E. M. Peterson, and L. M. De La Maza, "Susceptibility of human and murine Chlamydia trachomatis serovars to granulocyte- and epithelium-derived antimicrobial peptides," Journal of Peptide Research, vol. 61, no. 5, pp. 237-242, 2003.

[19] M. Donati, K. Di Leo, M. Benincasa et al., "Activity of cathelicidin peptides against Chlamydia spp," Antimicrobial Agents and Chemotherapy, vol. 49, no. 3, pp. 1201-1202, 2005.

[20] M. Donati, A. Di Francesco, R. Gennaro et al., "Sensitivity of Chlamydia suis to cathelicidin peptides," Veterinary Microbiology, vol. 123, no. 1-3, pp. 269-273, 2007.

[21] R. I. Lehrer, C. L. Bevins, and T. Ganz, "Defensins and other antimicrobial peptides," in Mucosal Immunology, P. L. Ogra, J. Mestecky, M. E. Lamm, W. M. Strober, and J. Bienstock, Eds., pp. 89-99, Academic Press, New York, NY, USA, 1998.

[22] B. Yasin, R. I. Lehrer, S. S. L. Harwig, and E. A. Wagar, "Protegrins: structural requirements for inactivating elementary bodies of Chlamydia trachomatis," Infection and Immunity, vol. 64, no. 11, pp. 4863-4866, 1996.

[23] M. Donati, V. Sambri, M. Comanducci et al., "DNA immunization with pgp3 gene of Chlamydia trachomatis inhibits the spread of chlamydial infection from the lower to the upper genital tract in $\mathrm{C} 3 \mathrm{H} / \mathrm{HeN}$ mice," Vaccine, vol. 21, no. 11-12, pp. 1089-1093, 2003.

[24] H. Fukushi and K. Hirai, "Immunochemical diversity of the major outer membrane protein of avian and mammalian Chlamydia psittaci," Journal of Clinical Microbiology, vol. 26, no. 4, pp. 675-680, 1988.

[25] S. Kahane, K. D. E. Everett, N. Kimmel, and M. G. Friedman, "Simkania negevensis strain $\mathrm{Z}^{\mathrm{T}}$ : growth, antigenic and genome characteristics," International Journal of Systematic Bacteriology, vol. 49, no. 2, pp. 815-820, 1999.

[26] S. Kahane, B. Dvoskin, G. Lustig, P. Dilbeck, and M. G. Friedman, "Partial characterization of Simkania negevensis isolates and comparison with Chlamydiales type strains," in Proceedings of the 4th Meeting of the European Society for Chlamydial Research, P. Saikku, Ed., p. 8, Bologna, Italy, 2000. 

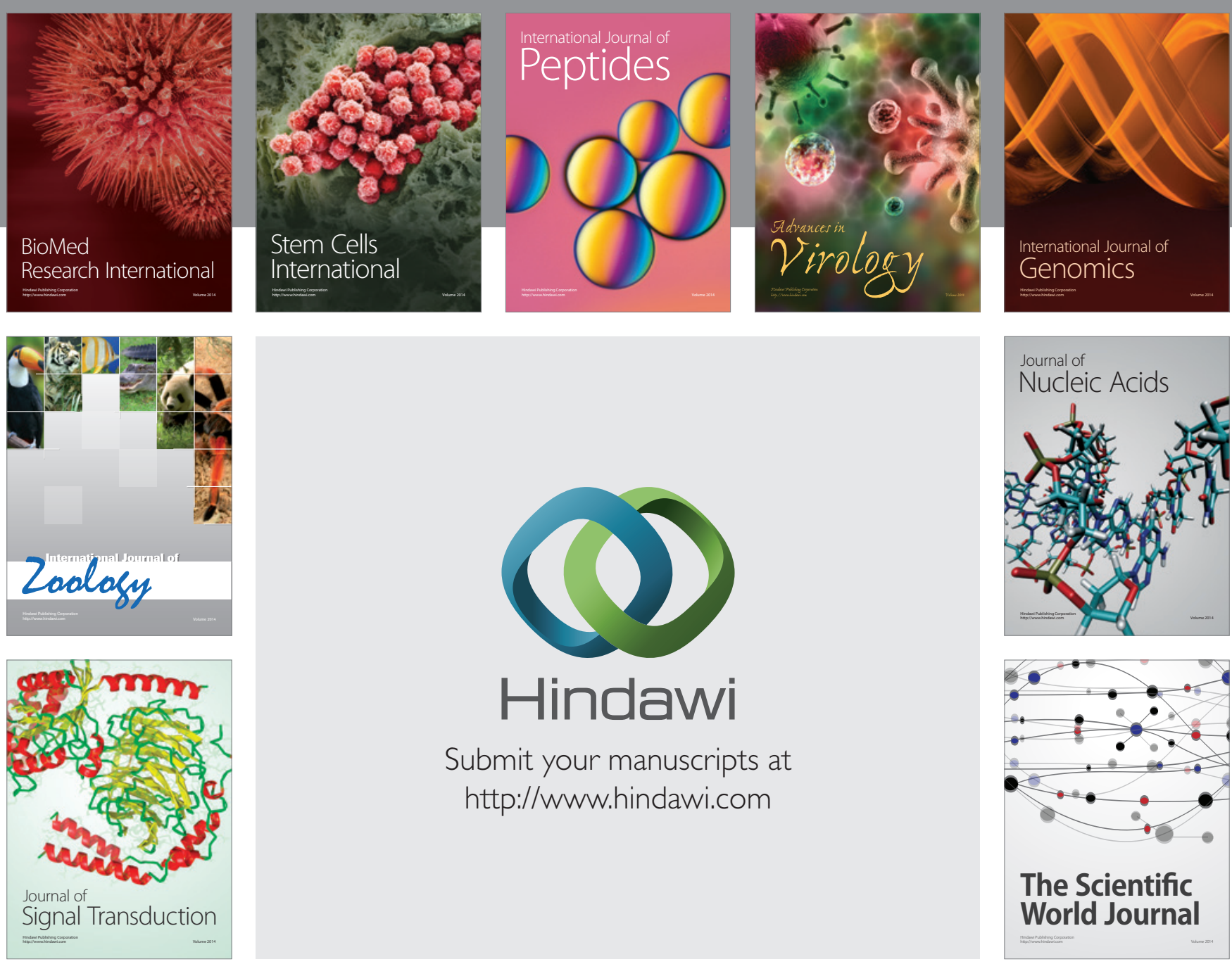

Submit your manuscripts at

http://www.hindawi.com
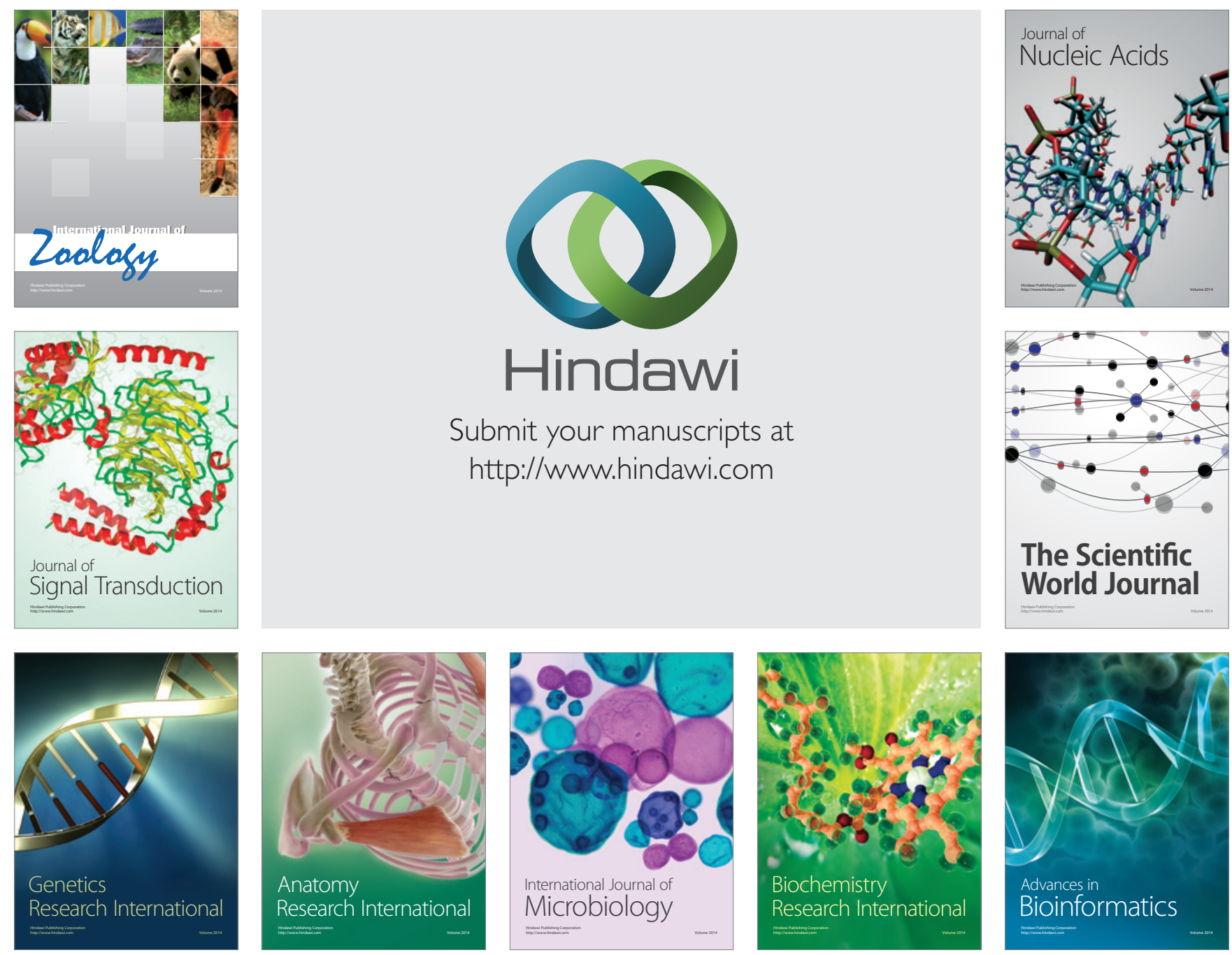

The Scientific World Journal
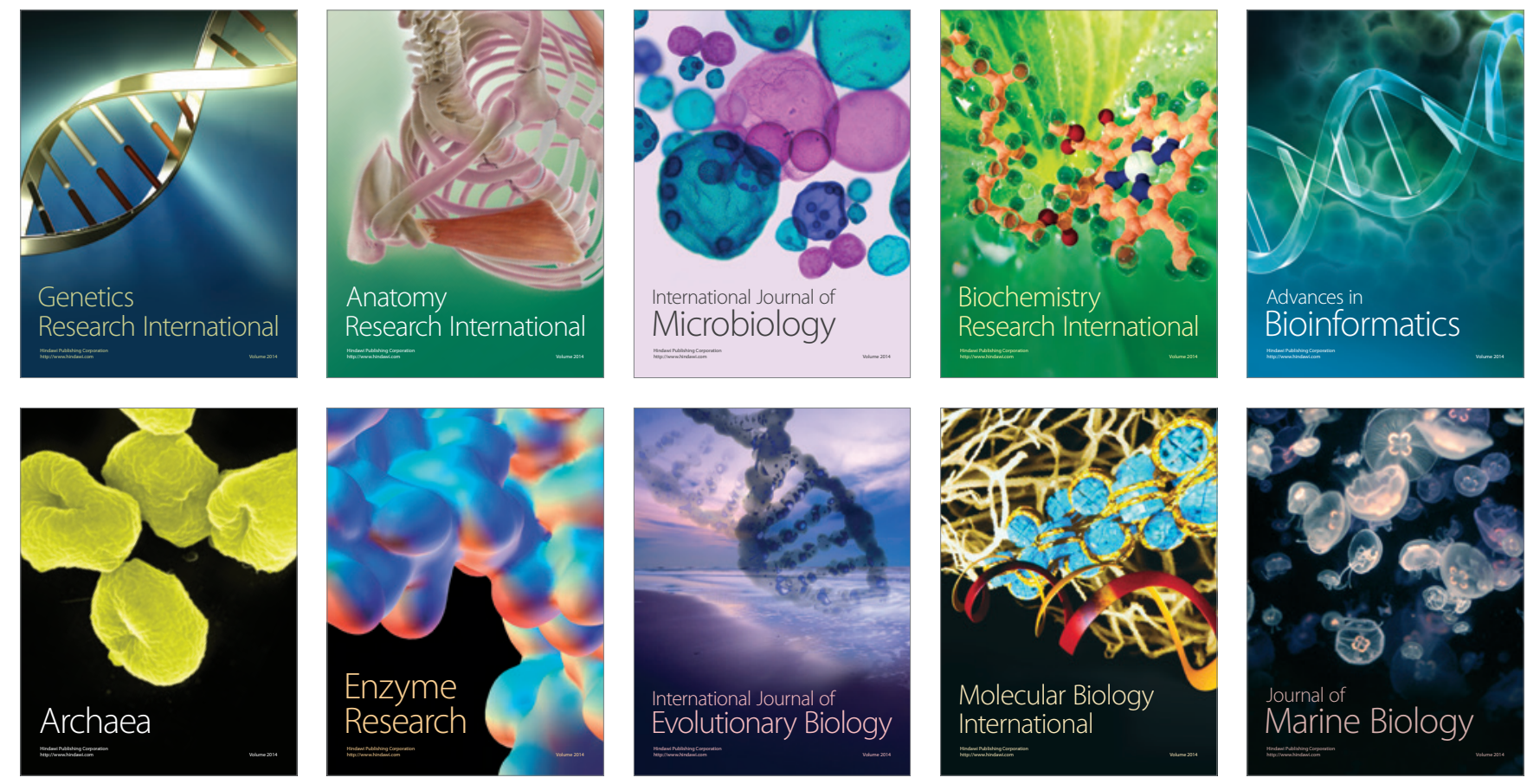